\title{
COMPARATIVE STUDY ON HEADLESS SHELL-ON BLACK TIGER SHRIMP (PENAEUS MONODON) PROCESSING UNDER SHIP-ONBOARD AND LAND BASED FACTORY FACILITIES
}

\author{
S. Ahmed ${ }^{* 1}$, M. H. Uddin ${ }^{2}$ and S. M. Istiak ${ }^{3}$ \\ Department of Zoology, Jagannath University, Dhaka, Bangladesh
}

\begin{abstract}
Shrimps is one of the main export commodities of the country and earns about more than 40 crores 47 lac US \$in 2017. Black Tiger (BT) shrimp alone contributes about $67 \%$ to the total shrimp export per year. Aquaculture shrimps are being processed in the land-based processing plant while wild catch is being processed onboard (fishing vessels) in the Bay of Bengal. A study was conducted to compare the yield and economic loss/gain of headless shell-on (HLSO) shrimp during processing by labor and crews at onboard (sea) and land based (land) factories. A total of twelve samples were examined; six for land and six for sea that was designated as "P" and "V", respectively. After beheading to produce HLSO, individual shrimp weight was measured. The average weight of an individual BT was $50.25 \pm 4.174 \mathrm{~g}$ for $\mathrm{V}$ and $51.13 \pm 3.66 \mathrm{~g}$ for P. Average yield from individual shrimp was $1.19 \mathrm{~g}$ higher in $\mathrm{P}$ compared to V. Found $23.10 \mathrm{~g}$ less production from $1 \mathrm{~kg}$ BT in $\mathrm{V}$ compare to $\mathrm{P}$ which is statistically significant $(\mathrm{P}=0.057)$. Our estimated results indicated that one vessel got $649.89 \mathrm{Kg}$ less product valued BDT 1,381,016 compare to land based processing plants due to processing by crews on board. Whole scenario predicts that more economic loss if we consider for 37 shrimp trawlers in operation.

Key words: Penaeus monodon, HLSO, Production, Yield, Economic loss, onboard.
\end{abstract}

\section{INTRODUCTION}

The fisheries sector is one of the most productive and sustainable areas which provides $60 \%$ of the animal protein for Bangladesh (DOF, 2018). This sector earned BDT 4,288 Crore by exporting 68,306 MT fisheries products to the EU, USA, Russia, Japan, China, Middle East, etc. in 2017-18 (DOF, 2018). Only shrimps contribute $58 \%$ to the export earnings of fisheries products. This sector contributes $3.57 \%$ to the national GDP and $25.30 \%$ to agricultural GDP (FRSS, 2017; DOF, 2018). Fish including shrimp and prawn is the second most valuable crops of all Agriculture crops and its production conduces to

*Author for Corresponding: <sumibd_15@gmail.com>; 2Quality Control Department, Ark Sea Foods Ltd., Chattogram, Bangladesh, ${ }^{3}$ Director, Deep Sea Fisher Ltd., 117/A old airport Road, Rangs Bhaban, Tejgaon, Dhaka, Bangladesh.

(C2020 Zoological Society of Bangladesh DOI: https: //doi.org/10.3329/bjz.v48i2.52378 
livelihoods and employment. There are 248 industrial fishing trawlers including 37 industrial shrimp trawlers and 67,669 artisanal boats are involved for capturing fish and shrimp from the Bay of Bengal (DOF, 2018). In 2017-18 about 0.63 million MT shrimps and fish were landed from the Bay of Bengal (DOF, 2018). The public sector corporation and private organizations have set up about 100 numbers of shore-based export-oriented fish processing plants, of which 76 plants are approved by the EU, where 29,000 employees (approx.) are involved (FFEAB, 2016). The export product scale comprises $72 \%$ unprocessed products (frozen whole), $24 \%$ prepared/processed and $4 \%$ other products (frozen freshwater fish). The exportable shrimps landed from two major sources, one is aquaculture and another is the Bay of Bengal. Sea shrimps are called wild/nature and culture shrimps called aquaculture products. Wild shrimps are getting a premium price that helps to earn more foreign currency. The major shrimps' based products for exports in Bangladesh are block frozen, IQF, SIQF, PUD (peeled un-deveined), P and D (Peeled and deveined), Skewer, Butterfly, Cooked, Battered, etc. Rest of the products are IQF/SIQF whole fish, dressed gutted fish, dried/salted and dehydrated fish, live Eel and crabs, etc. (BFFEA, 2008).

Bangladesh is one of the world's leading fish producing countries with a total production of 4.1 million MT (FRSS, 2017). Total fish production of the country shows a consistently increasing trend during the last 25 years, and the production is currently five times larger than that of 1983-84 (FRSS, 2018).

The government is trying to sustain this growth performance, which eventually ensures to achieve the projected production target of 4.55 million MT by 202021 and the shrimp and prawn industry can play a vital role here. This industry earns about more than 40 crores 47 lac US \$ in 2017-18 (DOF, 2018). Black Tiger (BT) shrimp alone contributes about $67 \%$ to the total shrimp export per year (Istiak, 2019). For achieving the production target, the accuracy of every step in production is necessary. As the wild/sea caught shrimps are getting a premium price, it requires more preferences to develop this sector. These shrimps are processed and packed at the vessels into the Sea immediately after catching. So the quality of the products is always best to compare to the landbased processing plant. Though all the industrial vessels are licensed as factory vessels, most of the crews are not well trained to process the products. Research predicts that there is significant yield loss during manual processing of HLSO at vessels (Captain Asom, Deep Sea Fisher Limited).How much shrimp's meat being lost during processing of HLSO, it was yet to evaluate. On the other hand, the labor of land-based processing plants are well trained and well monitored by 
their supervisors. The operation management is easier in land-based plants compare to the fishing vessel at sea. Usually, the land-based processing plants are getting better throughput/yield during the production of HLSO product. But the vessel are not getting better yield. That is way the production and performance of the labor/crews both in land-based processing plants and onboard vessels need to be investigated. It is assume that small quantity loss of raw material could be made huge economic loss when big amount of shrimp being processed. So, this research has been conducted to compare the yield of on-board (trawler) and land based (land factory) HLSO shrimp processing technique by labor and to find out economic loss or gain of same processed HLSO shrimp at onboard and land based condition.

\section{MATERIAL AND METHODS}

The experiment had conducted in a land based processing plant $(\mathrm{P})$ at Chattogram and in a shrimp vessel (V) at the Bay of Bengal during February 2017 to April 2018. The shrimp samples were collected by the shrimp vessels from the west of the Kohinoor point of the Bay of Bengal (20 $\left.58.5 \mathrm{~N}-91^{\circ} 19.0 \mathrm{E}\right)$. The land based processing plant was the control. The experiment was done using Sea caught Black Tiger shrimp during production of HLSO. About $12 \mathrm{~kg}$ of 13 counts shrimp (Black tiger) was used to conduct the experiment. Each $\mathrm{kg}$ contains 13 pieces of shrimp that means size of the shrimp was 13 count $/ \mathrm{kg}$. The samples were evaluated in two periods, one was $8^{\text {th }}$ February, 2017 to $20^{\text {th }}$ February, 2017 and another sampling were done from 28 $8^{\text {th }}$ March, 2018 to $10^{\text {th }}$ April 2018. The periods had marked as 'S1' and 'S2'. In each period, 6 samples were evaluated, three from vessels and three from land. The first sample (S1) was collected on 10 $10^{\text {th }}$ February, 2017 from a previously selected shrimp vessel, stayed on-board in the deep sea for 5 days and observed manual processing. Each time, 3 kilograms of 13 count shrimps were collected from main production. Weight was measured before and after processing. Three kg shrimp samples (V)were divided into 3 sub samples contained $1 \mathrm{~kg}$ weight (V1, V2 and V3). Another $3 \mathrm{~kg} 13$ count shrimp samples (P) were collected without influencing the regular production system and was transferred to the land-based processing plant for collecting data of land-based processing of HLSO. In the Land based processing plant, block frozen shrimp was deforested and the shrimp group $(\mathrm{P})$ was divided into 3 samples contained $1 \mathrm{~kg}$ weight named $\mathrm{P} 1$, P2 and P3, respectively and observed manual processing of HLSO product. The shrimp sample was tagged "A" for before beheading (headless) and "B" for after beheading (headless). Three samples of $1 \mathrm{~kg} 13$ count shrimps were processed at vessel and rest three samples of the same amount were processed in processing 
plant which were collected from the same vessel. Each sampling period $6 \mathrm{~kg}$ shrimp was used to conduct the study. The second sample (S2) was collected on $2^{\text {nd }}$ April, 2018 and the same procedures had been followed. Data were analyzed by SPSS (Nie, Bent, and Hull, 1970) and Excel 2010 (V14.0).

\section{RESULTS AND DISCUSSION}

A group of 13 individual's shrimp which made $1 \mathrm{~kg}$ set has taken to observe the production from head on to headless (HLSO) products. Data were collected from both establishment, those are in the shrimp vessel (V) at deep sea and in the land-based processing plant (P).Results shown that before beheading the average weight of a shrimp is same $(76.92 \mathrm{~g})$ because all groups contain $1 \mathrm{~kg}$ of shrimp. But after beheading, the average weight of S1VA and S2VA g were 50.85 $\mathrm{g}$ and $49.85 \mathrm{~g}$ respectively and all together the average weight is $50.35 \mathrm{~g}$. At the same time the average weight of S1PA and S2 PA were51.94 g and $51.13 \mathrm{~g}$ and all together the average weight is $51.54 \mathrm{~g}$. Result shown that the yield is $1.19 \mathrm{~g}$ higher at the land-based processing plant than that of the vessel. According to the table 1 , average yield of individual shrimp was $1.19 \mathrm{~g}$ higher in $\mathrm{P}$ compared to V. After producing HLSO the yield was $(50.35 \times 13) 654.55 \mathrm{~g}$ of $\mathrm{V}$ and $(51.54 \times 13) 670.02 \mathrm{~g}$ was $\mathrm{P}$ from $1 \mathrm{~kg}$ respectively which was $65 \%$ of $\mathrm{V}$ and $67 \%$ of P. Found $15.47 \mathrm{~g} / 2.31 \%$ less production from $670.02 \mathrm{~g}$ and $23.10 \mathrm{~g}$ less production from $1 \mathrm{~kg}$ BT in the $\mathrm{V}$ compare to $\mathrm{P}$. There is a significant mean

Table 1. Yield of the different group of samples in Vessel and Land-based processing Plant

\begin{tabular}{|c|c|c|c|c|c|c|c|c|c|}
\hline $\begin{array}{l}\text { Indi.I } \\
\text { kg }\end{array}$ & $\begin{array}{l}\text { L. } \\
\text { Plant }\end{array}$ & $\begin{array}{l}\text { Average } \\
\text { weight/ } \\
\text { sample.(g) }\end{array}$ & $\begin{array}{l}\text { Average } \\
\text { weight } \\
\text { /period(g) }\end{array}$ & $\begin{array}{l}\text { Average } \\
\text { weight in } \\
\text { total(g) }\end{array}$ & S. Vessel & $\begin{array}{l}\text { Average } \\
\text { weight/ } \\
\text { sample }\end{array}$ & $\begin{array}{l}\text { Average } \\
\text { weight/ } \\
\text { period(g) }\end{array}$ & $\begin{array}{l}\text { Average } \\
\text { weight in } \\
\text { total }(\mathrm{g})\end{array}$ & $\begin{array}{l}\text { Net } \\
\text { loss(g) }\end{array}$ \\
\hline 13 & S1P1A & 52.38 & & & S1V1A & 50.23 & & & \\
\hline 13 & S1P2A & 52.15 & 51.95 & & S1V2A & 51.85 & 50.85 & & \\
\hline 13 & S1P3A & 51.31 & & 51.54 & S1V3A & 50.46 & & 50.35 & 1.19 \\
\hline 13 & S2P1A & 51.08 & & & S2V1A & 50.00 & & & \\
\hline 13 & S2P2A & 51.08 & 51.13 & & S2V $2 A$ & 49.31 & 49.85 & & \\
\hline 13 & S2P3A & 51.23 & & & S2V3A & 50.23 & & & \\
\hline
\end{tabular}

Table 2: Comparison of shrimp weight before and after processing between plant and vessel sample using descriptive statistics (mean, median, standard deviation and range)

\begin{tabular}{lllll}
\hline & S1PA & S2PA & S1VA & S2VA \\
\hline Mean & 51.95 & 51.13 & 50.85 & 49.85 \\
Median & 52.02 & 50.00 & 51.00 & 49.00 \\
Std. & 3.244 & 4.034 & 2.072 & 5.523 \\
Deviation & & & & \\
Range & $45-59$ & $42-59$ & $47-58$ & $42-60$ \\
\hline
\end{tabular}


difference $(\mathrm{P}=0.00)$ between S1PB (Sample 1, processing plant, before beheading), S1PA and S2PB, S2PA at $1 \%$ level of significance. Actually mean value of S1PB (76.92) and S2PB (76.92) is greater than S1PA (51.13) and S2PA (51.143), respectively. Besides, S1VB (Sample 1, vessel, before de heading)

and S1VA; S2VB and S2VA shows a significant mean difference $(\mathrm{P}=0.00)$ at $1 \%$ level of significance. Mean value of S1VB (76.92) and S2VB (76.92) is greater than mean value of S1VA (50.85) and S2VA (49.85) separately (Table 2). Independent Sample Test (t-test) has done to find relationship between sample taken from Plant and Vessel. There is a significant mean difference between S1PA and S1VA $(\mathrm{P}=0.078)$ at the $10 \%$ level of significance. The sample result shows that mean of S1PA (51.95) is greater than S1VA (50.85). On the other hand, the mean difference of S2PA and S2VA are insignificance (10\%) but sample result shows that the mean value of S2PA (51.132) is greater than S2VA (49.85). As in combine, there is significant difference $(10 \%)$ between plants and vessel $(\mathrm{P}=0.057)$ and mean value of plant sample (51.95) is greater than vessel sample (51.13). As Table 1 shows that average value of plant (after beheading) is greater than vessel sample and difference value was $1.19 \mathrm{~g} / \mathrm{shrimp}$ which justify the statistical analysis.

In this research, about $1.19 \mathrm{~g}$. meat/shrimp loss had found during processing of HLSO at the shrimp vessel and $23.10 \mathrm{~g}$ less production from $1 \mathrm{~kg}$ BT in the V compare to P. One kg 12 to 20 count shrimp was sold BDT 2125. The cost of $23.10 \mathrm{~g}$ shrimps was BDT49.09. The economic loss was also statistically significant $(\mathrm{P}=0.057)$. In 2017 , the fishing days of the vessel where the study was conducted was 193 days. In 2017-18 FY this shrimp vessel produced approximate BDT 28,134 kg HLSO and earned BDT 59,784,750. Approximately one vessel got $649.89 \mathrm{Kg}$ less product and got less income BDT $1,381,016$ compare to land based processing plants due to processing by crews at sea. Whole scenario predicts that more economics loss when we calculate for 37 shrimp trawler in combines.

\section{CONCLUTION}

Among the fisheries products, shrimp is the most expensive one. Even though meat loss is small per individual shrimp, cumulative loss of a total catch is high which causes a good amount of monetary loss. Results revealed that the crews/operation management of the vessels was not aware of this loss. It was observed that during processing of HLSO at the vessel in the sea, hanging meat tear with the head. Hanging meat was not observed with head in the processing of HLSO in land base processing plant. Skill manpower, static condition and strong monitoring system may enhance the quality of product. If maximum 
utilization of raw material is ensure, ultimate success will come in earning lots of added foreign currency, satisfaction of producer and immense economic achievement. So, concern authority should take necessary steps to ensure the maximum utilization of raw material (Shrimp flesh), finds critical control point to ensure excellent quality and maximum profit.

Acknowledgement: This research was facilitated by Deep Sea Fisheries Limited, CPA Complex, Sadarghat, Chattogram, and ARK Sea Foods Limited, Sagorica, Fauzderhat, Chattogram. I would like to express my heartiest thanks and sincere gratitude to Mr. Amanullah Chowdhury, Vice Chairman and founder of the RANGS Group and Managing Director, Sea Resources Group for giving me the opportunity to conduct the experiment in his shrimp trawler.

\section{LITERATURE CITED}

BFFEA. 2008. Shrimp and Fish News : News Letter of Bangladesh Frozen Foods Exporters Association (BFFEA), Dhaka, Bangladesh. 2-41 pp.

DOF, 2018. National Fish Week Compendium (In Bengali). Department of Fisheries, Ministry of Fisheries and Livestock, Bangladesh, 160p.

FROZEN FOOD EXPORTER ASSOCIATION OF BANGLADESH 2016._http://www.bffea.bd.gov.pdf (adopted-2016).

FRSS, 2011. Fisheries Statistical Yearbook of Bangladesh. Department of Fisheries, Bangladesh, 2944.

FRSS, 2017. Fisheries Statistical Yearbook of Bangladesh. Department of Fisheries, Bangladesh, 3356.

NIE, N.H., BENT, D.H. and HULL, H.C. 1975. SPSS: Statistical package for the social scienecs. $2^{\text {nd }}$ edition, McGraw Hill Book Co., New York.

ISTIAK S, 2019, Impacts of Ban to Supplying Mother Shrimps to Hatcheries from the Bay of Bengal. Books of Abstract, Marine Biology and Oceanography, $8^{\text {th }}$ Biennial Fisheries Conference and Research Fair, PP-145.

(Manuscript received on 14 February, 2020 revised on 29 October, 2020) 